УДК 629.7.06-533.6

\title{
Анализ технических решений узлов стыковки систем термостатирования космических ракет
}

C. А. Бисун ${ }^{凶}$

Государственное предприятие «Конструкторское бюро «Южное» им. академика М. К. Янгеля»,

ул. Криворожская, 3, г. Днепр, 49008, Украина

$\triangle$ e-mail: sbigun58@gmail.com

Представлены технические решения известных в мировой практике узлов стыковки систем термостатирования воздухом низкого давления ракет космического назначения. Проанализированы приведенные технические решения.

По результатам анализа изложены выводы.

Ключевые слова: узлы стыковки, система термостатирования, космическая ракета.

\section{Аналіз технічних рішень вузлів стикування систем термостатування космічних ракет}

\section{A. Бizyн}

Державне підприємство «Конструкторське бюро «Південне» ім. академіка М. К. Янгеля», вул. Криворізька, 3, м. Дніпро, 49008, Україна

\begin{abstract}
Одним з найбільш важливих елементів наземного технологічного обладнання системи термостатування є вузли стикування (підключення) для космічних ракет-носіїв. Будучи кінщевою ланкою на шляху прямування термостатуючого продукиійного повітря від складної наземної стартової системи, вони відповідають за з'єднання (роз'єднання) иієї системи з бортом космічної ракети. Мета иієї роботи полягає в тому, щоб описати даний технічний напрям, а також розглянути і проаналізувати ряд технічних рішень, закладених в вузли стикування космічних ракетних комплексів. В роботі наведено технічні рішення відомих у світовій практиці вузлів стикування систем термостатування повітрям низького тиску ракет космічного призначення. Аналіз описаних технічних рішень показує, щзо застосовані в ракетно-космічній техніці або в загальнопромислових технічних системах конструкиії з приєднання - від'єднання систем термостатування побудовані або на основі жорстких систем зі зрізаних одноразових металевих елементів, або на базі торовидних пневмопружинних вузлів. Обидва варіанти досить конструкиійно складні та витратні. Крім того, всі представлені пристрої відносяться до виробів точної механіки і повинні бути співвісні при просторовому компонуванні. В результаті аналізу зазначених технічних рімень зроблений висновок про необхідність встановлення технічних вимог до вузлів стикування систем термостатування, найбільш важливі з них наведено в даній роботі.
\end{abstract}

Ключові слова: вузли стикування, система термостатування, космічна ракета.

(C) The Author(s) 2018. This article is an open access publication

This work is licensed under the Creative Commons Attribution 4.0 International License (CC BY)

http://creativecommons.org/licenses/by/4.0/

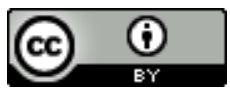

ONAFT

Open Access

\section{1 Введение}

Узлы стыковки (подключения) для космических ракет-носителей представляют собой один из наиболее ответственных элементов наземного технологического оборудования системы термостатирования. Являясь конечным звеном по пути следования термостатирующего продукционного воздуха от сложной наземной стартовой системы, они отвечают за соединение (разъединение) этой системы с бортом космической ракеты.

В мировой ракетно-космической технике эксплуати- руется множество разновидностей космических ракетных комплексов. Автором статьи была сделана попытка рассмотрения, изучения и анализа доступного опыта зарубежных компаний и патентов в области узлов стыковки систем термостатирования. При этом информация о них в публикациях ограничена.

Цель настоящей работы состоит в том, чтобы восполнить этот пробел и описать данное техническое направление, а также рассмотреть и проанализировать ряд технических решений, заложенных в узлы стыковки космических ракетных комплексов, находящихся в экс- 
плуатации в различных странах мира.

Прежде всего, стоит отметить, что узлы стыковки под разными наименованиями в том или ином конструктивном исполнении присутствуют во всех без исключения космических ракетных комплексах. Как правило, создателями и обладателями подобного рода комплексов становятся передовые в научно-технологическом отношении государства. Это США, Советский Союз и его правопреемница Россия, Франция, Китай, Япония, Индия и ряд других стран.

\section{2 Описание и анализ решений}

В начале работы акцентируем внимание на техническом решении узла стыковки, примененном на отечественном комплексе «Циклон-3» [1], приведенном на рис. 1. Узлы имеют вид рукавов цилиндрической формы длиной 455 мм внутренними диаметрами 100 и 150 мм, соответственно. Рукава являются гладкими и собраны из различных материалов, в число которых входят: металлопенополиуретан 2, прорезиненная баллонная ткань 3 , трикотажное полотно 4. Для устойчивости внутреннего сечения цилиндра к внешним воздействиям рукав армирован проволочной спиралью 1. Присоединение рукава к борту ракеты-носителя проводят вручную: надевают тканую оболочку 7 и пружину 6 на горловину термостатирования.

Затем тканую оболочку 7 снаружи завязывают тесьмой из капронового шнура 8. Другой конец рукава вручную натягивают на подводящий трубопровод термостатирования и зажимают хомутами. За несколько минут до старта ракеты-носителя установщик, освободивший захваты, отводят на некоторый угол; рукава натягиваются и сходят с горловины борта. Узлы стыковки сгорают в факеле газовой струи двигательной установки ракетыносителя, поэтому их относят к узлам разового действия.

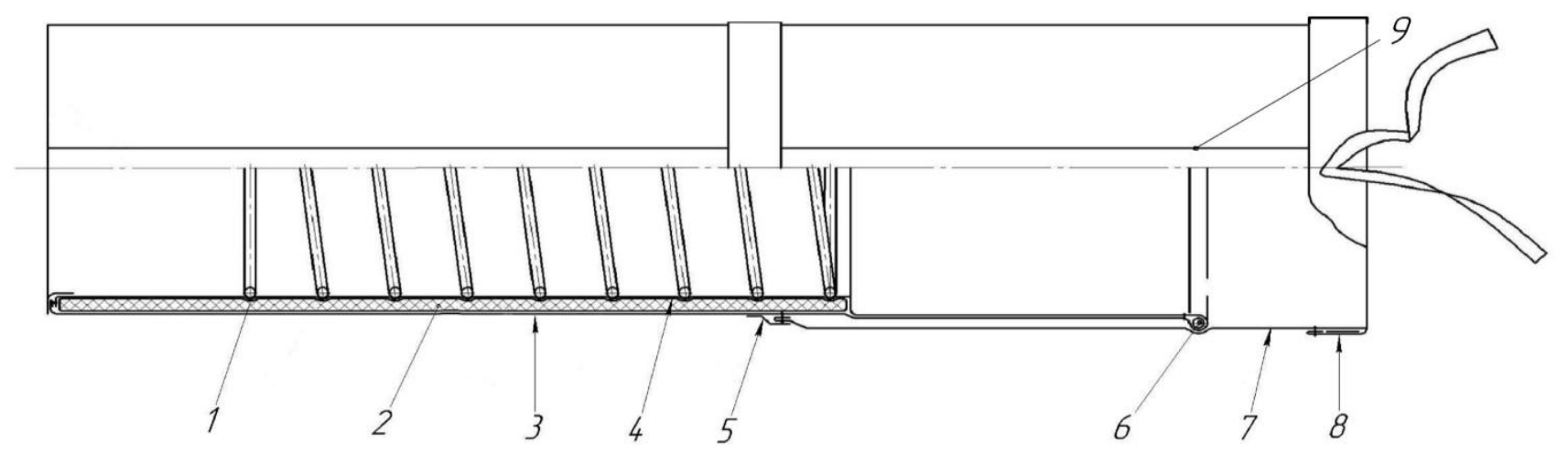

1 - спираль; 2 - пенополиуретан; 3 - полотно из прорезиненной ткани;

4 - трикотажное полотно; 5 - полотно из прорезиненной ткани; 6 - пружина;

7 - оболочка; 8 - тесьма из капронового шнура; 9 - полоса из прорезиненной ткани

\section{Рисунок 1 - Конструкция рукава системы термостатирования КРК "Циклон-3"}

Рассмотренная конструкция при всей простоте исполнения соединяет практически соосно расположенные в пространстве подводящий трубопровод термостатирования и принимающую горловину ракеты-носителя. Очевидно, в этом случае допускаемое рассогласование от соосности не должно превышать нескольких угловых градусов. Иначе рукав будет пережимать проходное сечение и борт ракеты не получит достаточного количества продукционного воздуха, что неприемлемо. Следовательно, рукав не может свободно изгибаться и перегибаться. А этот фактор, несомненно, является существенным недостатком. Кроме того, просадка горловины термостатирования при заправке ракеты-носителя компонентами топлива должна быть минимальной. В противном случае рукав из-за собственной избыточной жесткости обрывался бы с горловины ракеты-носителя, не выполнив своей задачи. Но главная проблема описанного технического решения заключается в неэффективном присоединении (отсоединении) рукава с помощью тесьмы из капронового шнура 8 к горловинам термостатиро- вания космической ракеты. Утверждать о герметичности и надежности в этом случае не приходиться, что свидетельствует о недостаточном качестве представленного технического решения. К тому же, качество завязывания капронового шнура проверить практически невозможно.

Тем не менее, представленное на рис. 1 техническое решение рукава, как основного элемента узла конструкции стыковки, прошло успешную отработку и эксплуатацию в составе почти 40 пусков указанного космического ракетного комплекса. В настоящее время комплекс снят с эксплуатации.

Представляет интерес техническое решение узла стыковки для подачи продукционного термостатирующего воздуха на борт космических ракет-носителей серии "Зенит" [1] и их усовершенствованных модификаций по программам "Морской старт" и "Наземный старт", приведенное на рис. 2.

Узел стыковки цилиндрической формы состоит из присоединительного элемента 11 , соединенного одновременно с гладким резиновым рукавом 5. Для придания 
жесткости в рукав завулканизированы металлические стаканы. Рукав снабжен двумя диаметрально расположенными провисающими поводками, выходящими из присоединительного элемента 11. Данный элемент представляет собой резиновый тор, внутри которого размещается пружина. С наружной стороны тора находится автомобильный золотник для подачи воздуха вовнутрь.

Герметизирующие заглушки 1 и 12 не позволяют загрязнениям из окружающей среды попадать в узел. Присоединительный элемент 11 с пневмопружинным механизмом вручную надевается на горловину термостатир- вания ракеты-носителя. При этом от портативного газового баллона специальным шлангом и присоединительной арматурой вовнутрь резинового тора подаётся воздух давлением до 2 МПа. После этого тор расширяется и вручную продевается на горловину термостатирования ракеты-носителя. Далее воздух из тора стравливается, пружина прижимает рукав за горловину. Другой конец рукава, аналогично с узлом стыковки на рис. 2, вручную натягивают на подводящий трубопровод термостатирования и зажимают хомутами.

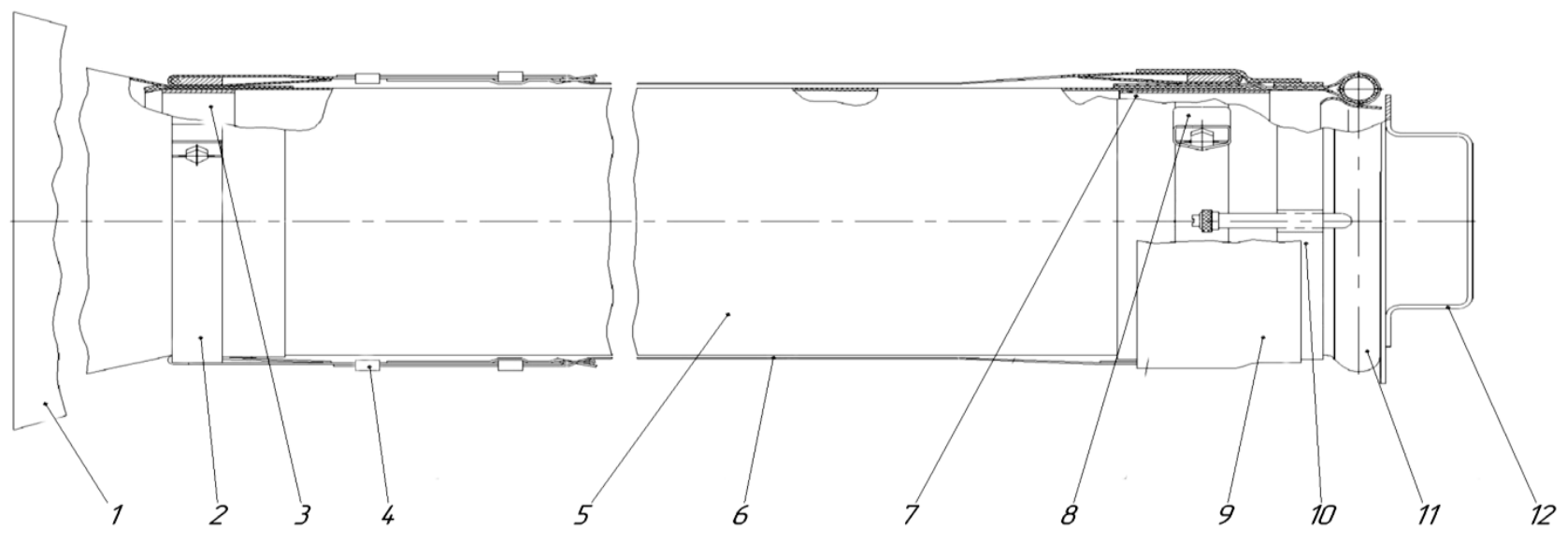

1, 12 - герметизирующие заглушки; 2 - скоба (2 шт.); 3 -кольияо; 4 - натяжитель; 5 - гладкий рукав; 6-ремень; 7 - кольијо; 8-защчитная трубка; 9 - предохранительное кольио; 10 - ремень; 11 - присоединительный элемент

Рисунок 2 - Конструкция рукава системы термостатирования КРК "Зенит "

Перед стартом ракеты-носителя установщик, освободив захваты, отклоняется в горизонтальное положение. В процессе отклонения установщика натягивается один из провисающих поводков и начинает стягивать рукав с горловины. По мере дальнейшего отклонения установщика натягивается и второй диаметрально противоположный поводок, окончательно отрывая рукав. Установщик удаляется от ракеты-носителя на безопасное расстояние. Поэтому узлы стыковки в данном случае, считаются узлами многоразового применения.

Приведенное на рис. 2 техническое решение, так же как и предыдущее на рис. 1 позволяет соединять в основном соосно расположенные в пространстве соединяющие элементы и не позволяет рукаву свободно изгибаться и перегибаться, суживая его эксплуатационные возможности. Кроме этого, усилие отрыва рукава от горловины борта ракеты отклонением установщика довольно значительно и составляет около 140 кгс. А принимая во внимание, что горловина находится, как правило, высоко, возникает значительный опрокидывающий момент (порядка 4-6 тм), что следует учитывать. Одновременно, наличие дополнительного газобаллонного оборудования и специально подготовленного персонала для работы с ним подтверждает сложность данного технического решения. Также при эксплуатации комплекса были случаи нештат- ного отсоединения этих рукавов в процессе старта ракеты, что, в свою очередь, могло привести к аварии.

Несмотря на указанные серьезные недостатки, узел стыковки, изображённый на рис. 2, прошёл отработку и эксплуатацию в составе космического ракетного комплекса “Зенит” и его модификаций, обеспечив более 50 пусков.

В настоящее время его эксплуатация продолжается. При этом указанному узлу уделяется особое внимание.

Несомненный интерес вызывает техническое решение на бортовое разъемное соединение (БРС) по патенту Российской Федерации [3], изображенное на рис. 3, 4, 5. Данное соединение системы воздушного термостатирования включает установленную на корпусе ракеты 1 горловину 2 и отделяемый патрубок 4, сопрягаемые между собой фланцами с коническими поверхностями, между которыми размещается резиновое уплотнительное кольцо для герметизации соединения. Фланцы стянуты Vобразными колодками 3 (рис. 4), которые охвачены тросовой системой, состоящей из двух ветвей 5 и 6, оснащенной наконечниками 7 и натяжителями 8. V-образные колодки закреплены к патрубку на упругих подвесах зигзагообразных плоских пружинах 9. На патрубке установлены два кронштейна 10, в которых размещены подвижные штоки 12 и цилиндрические стержни 13, сопря- 
гаемые с наконечниками 7 тросовой системы. Подвижные штоки фиксируются срезаемыми элементами 14 (рис. 5), а цилиндрические стержни 13 удерживаются стопорными кольцами 11, находящимися между штоками и кронштейнами. Цилиндрические стержни 13 имеют упорный бортик «а», отстоящий от торца «б» подвижного штока на расстоянии, равном или более диаметра «в» срезаемого элемента 14 (или ширины канавки на штоке, предназначенной для стопора). Оба подвижных штока 12 соединены канатами 15 с наземным механизмом отвода, который на рисунке 3 не показан. На подвижных штоках имеются опорные гайки 17 и установлены упругие буфеpa 16. На кронштейнах неподвижно закреплены втулки 18 , охватывающие наконечники тросовой системы и ограничивающие перемещения освобожденных концов тросов после разделения. Отделяемый патрубок 4 непосредственно, или через промежуточные детали соединяется с рукавом 19 наземной системы термостатирования.

Работа устройства осуществляется следующим образом. В исходном положении БРС имеет вид, показанный на рис. 3: горловина и патрубок с присоединенной к нему магистралью состыкованы и удерживаются колодками 3 , которые стянуты тросами посредством натяжителей 8 . Усилие вдоль тросов замыкается на стержнях 12, размещенных в отверстиях кронштейнов.

В процессе старта ракеты наземный механизм отвода коммуникаций создает усилие на тросах 15 (рис. 3) вдоль оси БРС и, соответственно, вдоль осей подвижных штоков 12.Происходит срез элементов 14, расфиксация, перемещение штоков до упора в буртики «в» цилиндрических стержней 13 и вытягивание их из цилиндрических стержней 13 наконечников 7 тросовой системы 5, 6. Поэтому усилия стягивания тросов снижаются практически до нуля. После упора штоков в буфера 16 (рис. 5) наземный механизм отводит патрубок и присоединенную к нему магистраль в безопасную зону. При этом колодки 3 (рис. 3), подвешенные на пружинах 9, соскальзывают с конических фланцев, освобождая соединение.

Разделение может произойти в результате вытягивания любого из двух штоков 12 (стержней 13), что повышает надежность устройства. После этого отверстие горловины 2 обычно закрывается автоматически запираемой крышкой люка, которая на рис. 3 изображена условно.

Анализ указанного на рис. $3,4,5$ технического решения показывает, что концепция БРС построена на базе одноразовых срезаемых элементов 14 и отличается конструктивной сложностью. Кроме того, стоит обратить внимание на наличие в конструкции большого количества механически обрабатываемых деталей вообще и деталей точной механики, в частности, а также дополнительного наземного механизма отвода. Перечисленные характеристики бесспорно усложняют и удорожают конструкцию, а в случае отмены пуска РКН в силу всевозможных причин требуют необходимости замены сработавшего БРС на новый из состава запасных частей, инструментов и принадлежностей. В целом рассмотренный вариант с точки зрения сложности, надежности и стоимости вряд ли можно назвать приемлемым.

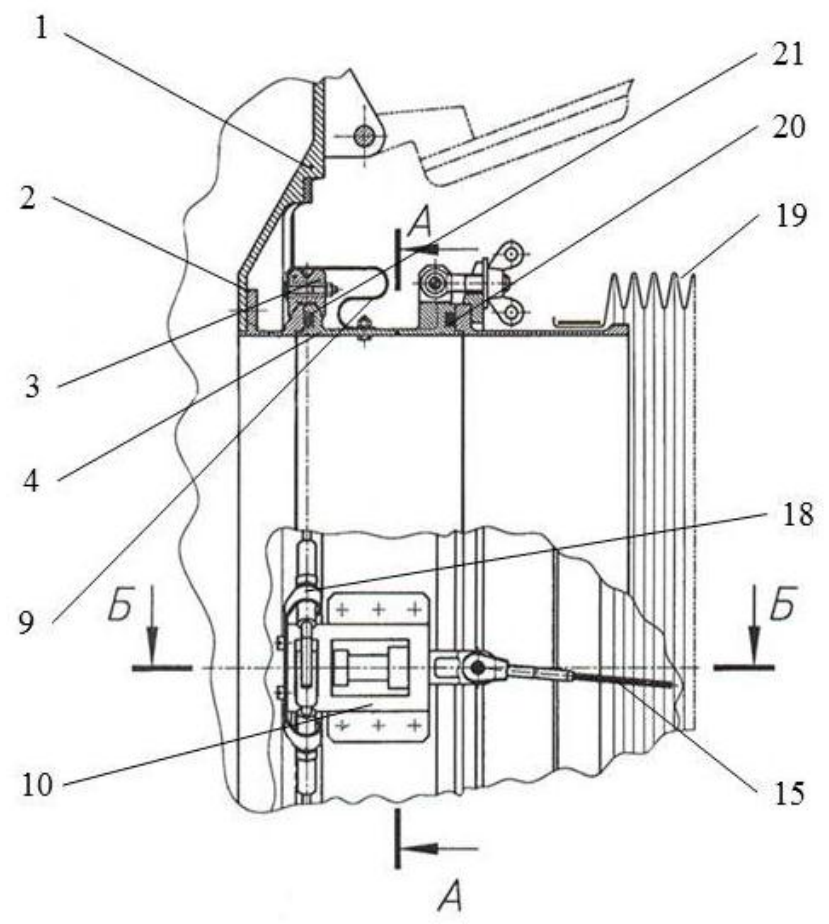

1 -корпус ракетьг; 2 - горловина; 3 -V-образнье колодки; 4-отделяемый патрубок; 9 - плоская пружина; 10 - кронштейн; 15 -канать; 18 -втулки; 19 - рукав, 20, 21 - резиновые уплотнительные кольца

Рисунок 3 - Бортовое разъемное соединение

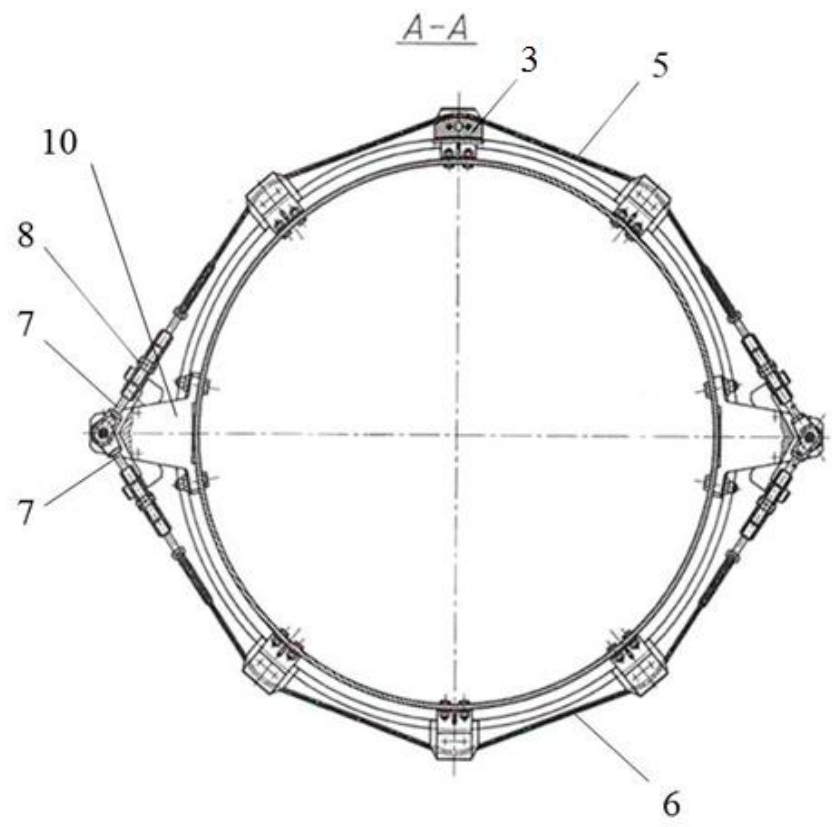

3 - V-образные колодки; 5,6 - ветви тросовой системы; 7-наконечники; 8-натяжители

Рисунок 4 - Разрез А-А БРС 


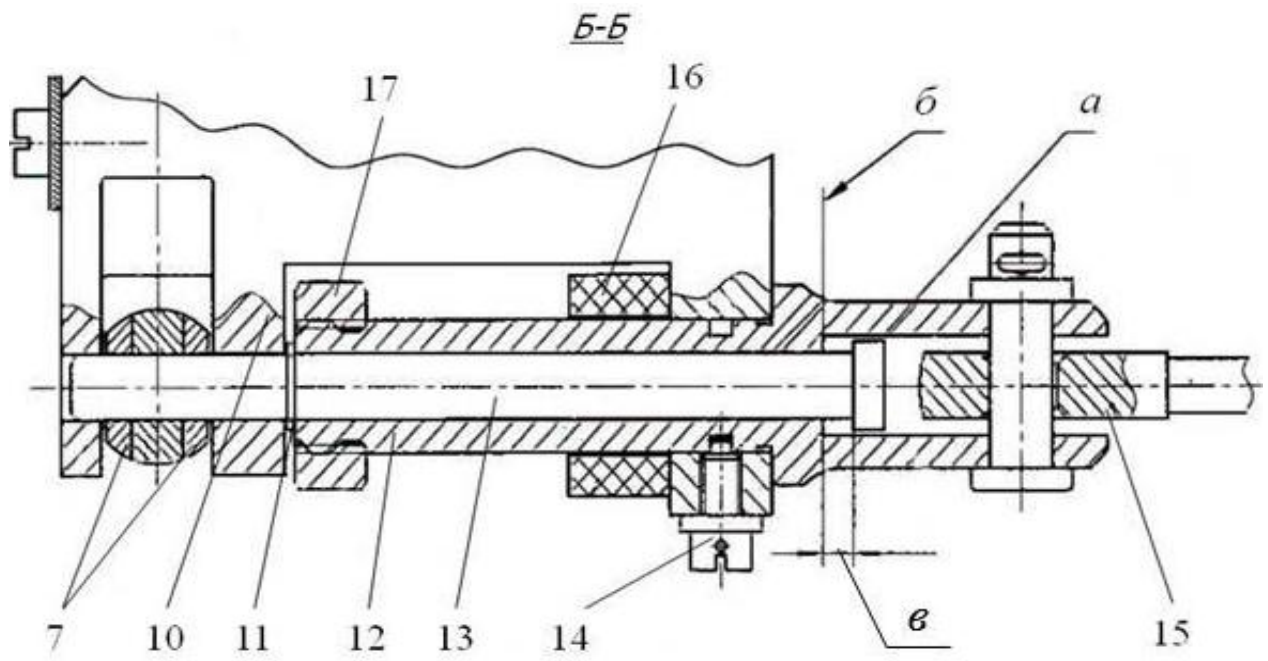

7 - наконечники; 10- кронштейн; 11-стопорное кольцо; 12 - подвижный шток; 13 - цүлиндрический стержень; 14 - срезаемый элемент; 15 -канат; 16 - упругий буфер; 17- опорная гайка

Рисунок 5 - Разрез Б-Б БРС

Известно техническое решение, приведенное на рис. 6, по патенту Франции [3] на разъемное соединение трубопроводов, приводимое в действие движением ракеты 2 в процессе старта. Герметичность этого соединения достигается тем, что для присоединения трубопровода системы термостатирования используется цельно трубный металлический сегмент 1. При этом разъединение магистралей происходит путем разрушения жесткого трубопровода по ослабленному сечению 3 - шейке с помощью специального механизма, кинематически связанного с наземным устройством отвода. Рассматриваемое устройство включает трубный сегмент 1 , соединяющий трубопроводы между наземным оборудованием и бортом космической ракеты 2. Ослабленное сечение 3 этого участка трубы автоматически разрушается в процессе старта с помощью механизма 4 и трубчатой муфты 5, обеспечивающего растягивающее усилие на сегменте 1 . Этот механизм содержит несколько наборов шатунов 6 , 7 , расположенных на сегменте 1 по обе стороны от ослабленного сечения 3 ,и рычаг 8 , шарнирно соединенный с каждым набором соединительных шатунов 6,7 и заканчивающийся полусферическим подшипником 9. Данный подшипник является шаровым шарниром на опорной поверхности 10 в виде круговой дуги поперечного сечения, образованного в трубчатой муфте 5, которая через систему тросов 11 соединяется с наземным устройством отвода (на рисунке не изображен).

Подобным техническим решением обладает устройство по патенту Франции [4] на рис. 7. В данном примере герметичное соединение и последующее разъединение магистралей осуществляется посредством V-образных секторов, охватывающие конические фланцы трубопроводов и деформируемых усилием тросов, связанных с наземным устройством отвода. Указанное устройство

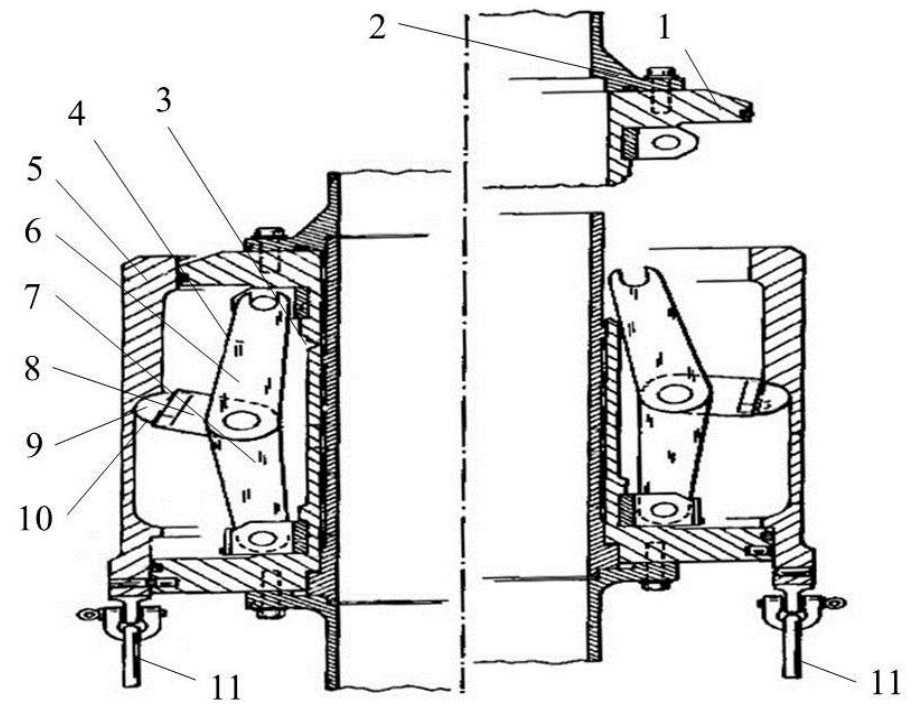

1 - трубный сегмент; 2 - борт ракеты; 3 - ослабленное сечение; 4 -механизм; 5 - трубчатая муфта; 6, 7-соединительные иатуны; 8- рычаг; 9 - полусферический подшипник;10 - опорная поверхность; 11 - система тросов

\section{Рисунок 6 - Устройство разъединения трубопроводов}

также как и предыдущее основывается на разрушении конструкции под воздействием сил, развиваемых наземной системой отвода. Устройство состоит из верхнего трубчатого корпуса 1 , который является частью борта космической ракеты, и нижнего трубчатого корпуса 2, который является частью наземного оборудования. Корпуса 1 и 2 соединены гофром 3, приваренным к верхней 
и нижней частям на стыке. Снаружи корпуса 1 и 2 удерживаются друг с другом трубчатой поперечной муфтой 4 , прикрепленной к фланцу 5 нижнего корпуса 2 и примыкающей к фланцу 6 верхнего корпуса 1. Фланец 6 верхнего корпуса 1 и верхняя часть муфты 4 удерживаются диском 7. Данный диск обладает упругой и пластической деформацией, благодаря хомуту 8 , соединенного с наземной системой отвода тросами 10 . При этом режущая часть ножа 9, который зафиксирован между поперечной муфтой 4 , фланцем 5 и нижним трубчатым корпусом 2 расположена в полости гофра 3.

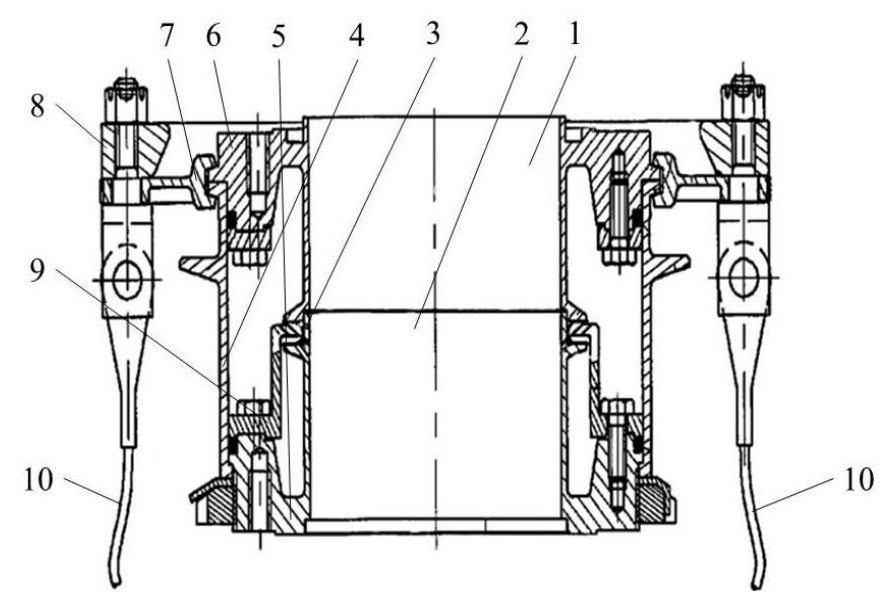

1 - верхний трубчатый корпус; 2 - нижний трубчатый корпусы; 3 - рифление (ослабленное сечение); 4 - трубчатая муфта; 5, 6- фланцы; 7-диск; 8-хомут; 9-нож; 10 - тросы

\section{Рисунок 7 - Устройство разъединения трубопроводов}

Явными недостатками устройств, указанных на рис. 6,7 является конструктивная сложность, большое количество точных деталей, а также увеличенное усилие разделения, вызванного деформацией охватывающих фланцы секторов. Последнее обстоятельство может оказаться проблематичным для вертикально стартующей ракеты из-за ограничения поперечной силы, действующей на большом плече и способной вызвать возмущения в начальной стадии полета. Кроме того, недостатком является одноразовость применения, что в случае отмены пуска при сработавшем устройстве приведет к необходимости его восстановления и соответствующим затратам для осуществления миссии.

Похожими характерными особенностями обладают также технические решения разъемных соединений, приведенные: в патенте Российской Федерации [5] на быстроразъемное соединение криогенных заправочных коммуникаций наземного стартового комплекса с ракетой, в патенте Российской Федерации [6] на клапан общепромышленной трубопроводной арматуры, в патенте Российской Федерации [7] на запорный узел шиберного затвора для общепромышленных трубопроводов, в патенте сийской Федерации [8] на разъемное соединение системы термостатирования космической головной части, в патен- те Российской Федерации [9] на узел системы термостатирования летательного аппарата, в авторском свидетельстве СССР [10] на запорно-регулирующее устройство трубопроводов технических систем. Выпущен целый ряд других подобных патентов Кореи, США, Японии.

Анализ описанных технических решений показывает, что примененные в ракетно-космической технике либо в общепромышленных технических системах конструкции по присоединению - отсоединению систем термостатирования построены либо на основе жестких систем из срезаемых одноразовых металлических элементов, либо на базе торовидных пневмопружинных узлов. Очевидно, первое исполнение узла стыковки имеет сложный конструктивный состав с привлечением специальной наземной системы отвода. В практике бывает так, что при срабатывании системы отвода и, как следствие, отсоединении узла стыковки от борта, пуск ракеты - носителя в силу различных причин может быть отменен. В этом случае требуется определенное время для замены сработавшего узла на новый узел из состава запасных частей.

Второе исполнение требует наличия на старте дополнительного газобаллонного оборудования для задействования пневмопружинного механизма узла стыковки и специально обученного персонала для работы с ним.

Как видно, оба варианта достаточно конструкционно сложные и затратные. Кроме того все представленные устройства относятся к изделиям точной механики и должны быть соосны в пространственной компоновке.

\section{3 Выводы}

В результате анализа, приведенных в настоящей статье технических решений следует вывод о том, что, должны быть установлены технические требования [1], [11] к узлам стыковки систем термостатирования. Наиболее важные из них, по мнению автора, следующие:

- герметичность и надежность обеспечения герметичности, включая надежность соединения;

- многократное присоединение и отсоединение, при необходимости;

- автоматическое отсоединение от ракеты космического назначения при минимальных усилиях;

- минимальное силовое воздействие на борт ракеты в процессе подачи термостатирующего воздуха и при отсоединении от борта;

- компенсация технологических, монтажных и просадочных смещений и погрешностей, с сохранением при этом, связей между ракетой и наземной системой термостатирования;

- обеспечение геометрии соединений с учетом внешних силовых и прочих воздействий и заданного расхода воздуха;

- исключение возможных загрязнений;

- сохранение целостности и живучести в процессе воздействия эксплуатационных факторов при соблюдении длительных гарантийных обязательств;

- обладание низкой теплопроводностью и устойчивостью к биологическим вредителям, хлоридам, солнеч- 
ной радиации и другим воздействующим факторам;

- наличие невысокой стоимости по сравнению с зарубежными аналогами с целью обеспечения конкурентоспособности на рынке пусковых услуг.

На основании проведенных исследований приходим к общему выводу о том, что создание оптимальных и высокоэффективных узлов стыковки может быть возможным после выполнения указанных требований.

\section{Литература}

1. Бигун С.А., Хорольский М.С. и др. Типы и конструктивные особенности узлов стыковки систем термостатирования головных блоков и отсеков ракет-носителей космических аппаратов // Космическая техника. Ракетное вооружение: Сб. науч.-техн. ст. - 2013. - Вып. 1, - Днепропетровск: ГП «КБ «Южное». - 123 с.

2. Описание изобретения по патенту Российской Федерации №2473003-C1, 2011 г., МПК7 F16L 37/20. - 10 с.

3. Описание изобретения по патенту Франции №2658479-А2, 1990 г., Мкл5 В64G 5/00, 1/40. - 2 с.

4. Описание изобретения по патенту Франции №2685903-A1, 1992 г., Мкл5 B64G 5/00. - 2 с.
5. Описание изобретения по патенту Российской Федерации №2260737-C2, 2012 г., МПК F16L 37/20. - 9 с.

6. Описание изобретения по патенту Российской Федерации №2260732-C1, 2005 г., МПК F16L 3/08 F16L 39/04. $-8 \mathrm{c}$.

7. Описание изобретения по патенту Российской Федерации №2116539-C2, 1998 г., МПК F16L 3/08. - 6 с.

8. Описание изобретения по патенту Российской Федерации №2596706-C1, 2016 г., МПК F16L 37/00 B64G 5/00. $-12 \mathrm{c}$.

9. Описание изобретения по патенту Российской Федерации №2158215-С1, 2000 г., МПК В64G 1/22 В64C 1/14. $-8 \mathrm{c}$.

10. Описание изобретения к авторскому свидетельству CCCP №1348594-A1, 1985 г., МПК F16К 3/08. - 3 с

11. Дунаев Д.В. Анализ применения методов экспертных оценок при планировании наземной экспериментальной отработки изделий ракетной техники // Вестник Московского авиационного института, Т.23, №2.- 2016. Москва: МАИ. - 92 с.

\section{The analysis of technical decisions of knots of docking of systems thermostatic control space launch-vehicles}

\section{S. Bigun}

Yuzhnoie State Design Office, 3 Krivorozhskaya St, Dnepr, 49008, Ukraine

Technical decisions of attachment assemblies known in world practice of systems thermostatic control are presented by air of low pressure of rockets of space appointment. The resulted technical decisions are analysed. By results of the analysis conclusions are stated.

Keywords: Thermal conditioning systems; Attachment assemblies; Integrated launch vehicles

\section{Reference}

1. Bigun S.A., Khorolsky M.S. (2013) Tipi i konstrurtivnie osobennosti uzlov stikovri sistem termostatirovaniya golovnih blokov i otsekov raket-nositelei kosmicheskih apparatov. Kosmicheskaya tehnika. Raketnoe vooruzhenie, vip. 1, 123 p. (in Russian)

2. Opisanie izobreteniya po patentu Rossiiskos Federatsii №2473003-C1, 2011 ., MPK7 F16L 37/20. 10 p. (in Russian) 3. Opisanie izobreteniya po patentu Frantsii №2658479-A2, 1990 г., Мкл5 B64G 5/00, 1/40. - 2 p. (in Russian)

4. Opisanie izobreteniya po patentu Frantsii №2685903-A1, 1992 г., Мкл5 B64G 5/00. - 2 р. (in Russian)

5. Opisanie izobreteniya po patentu Rossiiskos Federatsii №2260737-C2, 2012, MPK F16L 37/20. - 9 p. (in Russian)

6. Opisanie izobreteniya po patentu Rossiiskos Federatsii №2260732-C1, 2005, MPK F16L 3/08 F16L 39/04. - 8 p. (in Russian)
7. Opisanie izobreteniya po patentu Rossiiskos Federatsii №2116539-C2, 1998, MPK F16L 3/08. - 6 p. (in Russian)

8. Opisanie izobreteniya po patentu Rossiiskos Federatsii №2596706-C1, 2016, MPK F16L 37/00 B64G 5/00. - 12 p. (in Russian)

9. Opisanie izobreteniya po patentu Rossiiskos Federatsii №2158215-C1, 2000, MPK B64G 1/22 B64C 1/14. - 8 p. (in Russian)

10.Opisanie izobreteniya $\mathrm{k}$ avtorskomu svidetelstvu SSSR №1348594-A1, 1985, MPK F16K 3/08. - 3 p. (in Russian)

11. Dunaev D.V. (2016) Analiz primeneniya metodov ekspertnih otsenok pri planirovanii nazemnoi eksperimentalnoi otrabotki izdelii raketnoi tehniki. Vestnik Moskovskogo aviatsionnogo instituta, 23(2), 92 p. (in Russian)

Received 08 July 2018 Approved 04 September 2018 Available in Internet 30 October 2018 